\title{
Effect of high power ultrasonic treatment on whey protein foaming quality
}

\begin{abstract}
High power ultrasonic energy at $20 \%, 40 \%$ and $60 \%$ amplitude was applied on whey protein suspension at concentrations of 100,150 and $200 \mathrm{~g} \mathrm{kgī} 1$ for 5, 15 and 25 min to improve its foaming quality. Ultrasound-treated whey protein suspension at $200 \mathrm{~g} \mathrm{kgī} 1$ showed improvement in terms of increased foaming capacity by $18 \%$, foam stability by $35 \%$, consistency index by $18 \%$, storage modulus by $17 \%$, loss modulus by $26 \%$ and viscosity by $21 \%$ compared with untreated whey protein. For maximally ultrasound-treated samples of $60 \%$ amplitude treated for $25 \mathrm{~min}$, the improved whey protein foams also had a $46 \%$ increase in the number of more evenly distributed fine bubbles which had a size smaller than 0.0025 $\mathrm{mm} 3$ as imaged using X-ray microtomography.
\end{abstract}

Keyword: Aeration; Foam; Ultrasound; Whey protein; X-ray microtomography 